\title{
Ida Merello, «Racconti fantastici di Balzac»
}

\section{Marco Stupazzoni}

\section{OpenEdition}

\section{Journals}

\section{Edizione digitale}

URL: https://journals.openedition.org/studifrancesi/26518

DOI: 10.4000/studifrancesi.26518

ISSN: 2427-5856

\section{Editore}

Rosenberg \& Sellier

\section{Edizione cartacea}

Data di pubblicazione: 1 avril 2007

Paginazione: 193

ISSN: 0039-2944

\section{Notizia bibliografica digitale}

Marco Stupazzoni, «lda Merello, «Racconti fantastici di Balzac»», Studi Francesi [Online], 151 (LI| I) |

2007, online dal 30 novembre 2015, consultato il 23 novembre 2021. URL: http://

journals.openedition.org/studifrancesi/26518; DOI: https://doi.org/10.4000/studifrancesi.26518

Questo documento è stato generato automaticamente il 23 novembre 2021.

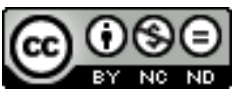

Studi Francesi è distribuita con Licenza Creative Commons Attribuzione - Non commerciale - Non opere derivate 4.0 Internazionale. 


\title{
Ida Merello, «Racconti fantastici di Balzac»
}

\author{
Marco Stupazzoni
}

\section{NOTIZIA}

IDA MERELLO, «Racconti fantastici di Balzac», in «Atti della Accademia ligure di Scienze e lettere», Serie VI, Volume VII, 2004, pp. 111-119.

1 Oggetto di questo breve ma interessante studio è la produzione narrativa balzachiana riconducibile al genere fantastico, un genere che, soprattutto negli anni venti e trenta dell'Ottocento, ha goduto di notevole successo in Francia come altrove. L'analisi de Ida Merello si focalizza in modo particolare su alcuni romanzi / racconti pubblicati tra il 1820 (Le Centenaire) e il 1835 (Séraphîta) che si pongono certo "come una sintesi di tendenze alla moda» (p.113), ma che testimoniano allo stesso tempo della rivisitazione e della rielaborazione del tutto personali da parte di Balzac di alcuni miti che hanno dominato l'immaginario romantico: Faust, Don Giovanni, il vampiro e l'ebreo errante.

2 Il genere fantastico, osserva l'A. in conclusione del suo intervento, consente a Balzac di «rappresentare attraverso una mitologia ben identificabile certe ossessioni esistenziali» e di «suggerire un mondo spirituale compensativo e consolatorio, che consenta di sfuggire, attraverso il sogno, alla prigionia della société de l'argent» (p. 119). 